Int.J. Hum. Soc. Dev. Res.

ISSN (P):2521-1439; ISSN (E):2523-4331

Volume 1, № 1, 2017, 19-41

DOI:10.30546/2523-4331.2017.1.1.19

\title{
Teaching Grammar to Pakistani ESL learners and Essay Writing Skills: A Case study of COMSATS Lahore Undergraduates
}

\author{
Maryam JAHANGIR \\ COMSATS Institute of Information Technology, Pakistan
}

(C) The Author(s) 2017

\begin{abstract}
English language has a sound, complex grammar and ESL learners face difficulties in application of these grammatical rules while writing essays. This paper highlights the major errors that Pakistani students make during the process of learning English as a second language and some reasons which hinder the process of learning and even hinder their academic and writing growth. It also sheds lights on the fact that grammatical instructions fail to improve these students' essay writing skills in second language. The major focus is on undergraduate students at the beginning of writing creatively with less exposure to English language and grammar. It is observed that students try to learn grammatical rules and can learn them in isolation but when it comes to their own writing, they fail to apply these rules in their compositions. The research aims to check the reasons of ineffectiveness of grammar instructions on grammar knowledge and writing proficiency in First Semester students of English language at COMSATS Institute of Information Technology Lahore. The participants were 200 undergraduate students of first semester at COMSATS Lahore. A questionnaire was used to examine the perceptions of students. Subject-verb agreement, tenses and articles were found as major mistakes in students' essays. The findings show that rote-learning, L1 interference, large classroom size, excessive use of SMS language and difficult English grammar as compare to Urdu language grammar, are the major reasons of grammar errors among students in essay writing and cause failure of grammar instructions. This study gives implications for further research to find the new sources to teach grammar more effectively and the possibility of integrated grammar teaching techniques which may help students to improve.
\end{abstract}

(C)2017.All rights reserved

\section{ARTICLE HISTORY}

- Received: $10 / 11 / 2016$

Accepted: 09/03/2017

Published online: 26/04/2017

\section{KEYWORDS}

Grammar instructions, second

language acquisition, common errors, essay writing

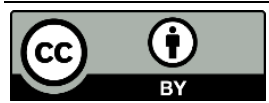

www.ijhsdr.com 


\section{Introduction}

Writing is a literacy skill and a complex form of self expression. It is an exhibition of cognitive, visual, conceptual and motor potentials ( Mercer \& Mercer, 2004). English writing is a difficult task for the Pakistani students due to the lingual and cultural differences. These differences may cause the grammatical errors, composition problems and inappropriateness of presentation of ideas in English (Cai, 2004).

English is a common language being understood and used for communication in the world. It is considered as a key to success. The college students in Pakistan have taken twelve years coaching for English language but do not have mastery in English writings. Commonly, they take it just to pass the examination instead to have hands on practice (Kannan, 2009). According to Commeyras and Inyega (2007) in all languages some students face severe reading problems besides all other supporting factors that grow in the form of writing difficulties.

\section{Literature Review}

Grammar is the sound, structured, and meaningful system of language. All languages have structure and each language has its own grammar. The language can only be understood if one is apt in that language's grammar and vocabulary. The written expression can only be possible if grammar is learnt completely. Grammar is important because it leads the learner towards understanding of language and getting command over it. In academics, students are judged by their command on English language, their vocabulary and how effectively they utilize this knowledge in their written tasks. Research suggests that rote teaching of grammar does not serve students well. Students do not transfer these grammar rules in their writing (Harris \& Rowan, 1989; Hillocks, 1986). Effective grammar instruction begins with students' prior knowledge of grammar and it helps them to use this knowledge as they write. Teachers can connect students' knowledge of oral language to written language to clarify abstract grammatical rules so that students can write and read with greater competence.

In addition, grammatical knowledge is also crucial for students hoping to climb the ladder of academia (Nail, n.d.). For a successful academic and professional life, written and good communicative skills are demanded by all organizations. Instructors also realize that the employer in the professional world, and many of the students themselves, believe that the only way to enter and succeed in that world is to learn and follow the rules of English language. Many ESL learners are required to pass a national or international exam in order to move towards their professional life. Their performance in these tests determines their 
future and it can be said that these exams are their future-makers. A major part of these tests is based on grammar and written composition. To do well in the test, grammar and practicing it in writing, is a must for these learners. If they ignore grammar, they cannot write well and at the end will suffer.

Essay writing is very important for undergraduates and writing is the basic part of academic and professional life. The students, who can write correctly and effectively, get good grades in their academic lives and these writing abilities are highly paid by employers in their professional lives afterwards. Unfortunately, the major problem which is identified by a lot of studies is essay writing; they are unable to perform well in it. According to Ahmed (2010), in his study at Halwan Faculty of English in Egypt, Essay writing, which constitutes a problem for many ESL/EFL students worldwide, is major challenge for many students. Despite numerous approaches to the teaching of writing having evolved from different teaching methods, tackling EFL writing is still one of the most challenging areas for teachers and students of English .These students still experience some problems in the cohesion and coherence of their English essay writing. In fact, producing a coherent piece of writing is an enormous challenge, especially in one's second language.

The dilemma is how to teach grammar effectively because students cannot translate the learnt rules of grammar when it comes to writing. At advanced level students learn English to improve their creative and technical writing. With regular instructions of grammar by teachers in ESL classrooms, students get the idea to apply grammar in isolated sentences but cannot apply successfully in their own essay writing compositions. When they are given some topic to shed light on it, majority fails to apply those grammar rules which they learnt few days ago in the same classroom. Any teacher of English as a second language is ultimately faced with a dichotomy between knowledge and performance, especially if they teach courses with a major component of written expression. Murrow (2005) says that a class of English language learners can perform adequately in routine grammatical exercises, but they fail signally to translate this demonstrated knowledge into reality when they face some task of writing original prose. This is not because they have not been taught but not effectively taught so that they can transform that knowledge of grammar in their writing. Taking these ideas into consideration, this study attempts to identify the grammatical errors which students make in writing English essays in order to help teachers of English tackle the problem and to indicate the points of weakness in English writing

The complete understanding of grammar, demands successful implementation of those grammatical rules which were learnt in ESL class rooms. Unfortunately, this knowledge seems largely ineffective when the students write. Their essays are poor in coherence and structure, full of grammatical mistakes. Teorey (2003) realized that after years of teaching he begins each semester with the 
expectation that either his students already know how to use grammar correctly or they can and will use the handbook he provides to teach themselves the grammar rules and conventions they need to know. But many errors still appear in the students' papers and written tasks. An extreme view from Braddock et al (1963) is that teaching of grammar seldom improves writing, and may even be detrimental (Murrow, 2005).

\section{Present Study}

It is important to find out the most common errors in students' essay writing. It is very important to address this problem area which affects individuals, communities and society as a whole. The research aims to check the common grammar errors in essay writing of First Semester students of English language at COMSATS Institute of Information Technology Lahore. It is observed that students try to learn grammar rules and can learn them in isolation. They can apply these rules in isolated sentences as well but when it comes to their own writing, they fail to apply these rules in their compositions. Grammar errors in writing are a common problem facing college transition students. The errors most frequently made by these students are mostly omission of letters, fragments, comma splice, which are often viewed as errors in punctuation (Shaughnessy, 1977). This study purports to identify and categorize undergraduate Pakistani students' grammatical errors in English essays in order to find out the sources of those errors and a way of remediation in future studies.

Most of the students entering the ESL classes do not understand and cannot explain how Standard English grammar functions, which limits their ability to compose acceptable essays, proofread their work, and review their peers' writing. In COMSATS Lahore students are from rural and urban areas both, but majority is from other cities. They are having different educational backgrounds e.g F.sc, A Levels, I Com, etc. This mix ability creates issues for teachers to decide instruction level and teaching methodology. The grammar lessons and instructions are effectively planned for these ESL learners but it is found that majority of the students make several grammatical mistakes in essay writing. It would be analyzed that why students cannot relate what they learn about grammar in their essays?

The primary goal of the study is to examine students' essays along with their attempts of doing context-free grammar exercises and then finding the gap between them. This study is an attempt to provide an overview of most common grammatical errors committed by ESL learners and the reasons behind them. The study intends to do an effort to make grammar instructions effective and helpful for the creative writing of students so that they can get benefit, can learn application of grammar effectively and as a result can become proficient in writing. It seeks to verify the findings of previous researches which say that isolated grammar teaching does not improve writing skills of students. It investigates the issue of grammatical

Int.J. Hum. Soc. Dev. Res.

Volume 1, № 1, 2017.19-41 
difficulty from the perspective of university-level Pakistani ESL learners in relation to their overall L2 proficiency and L2 performance and knowledge.

\section{Second Language (L2) Acquisition and Importance}

As cited in Jansson (2005) second language acquisition refers to learning the language that is in majority in the society or is the official language, but is not the learner's mother tongue. Foreign language acquisition, on the other hand, is when a learner acquires the language of another country (Cook, 2003). Second language acquisition is referred to by the term SLA. According to Van Patten (2005), first language learning and second language acquisition are similar at the core. Therefore, it is reasonable to assume that just as the child learns a first language through exposure to a vast amount of auditory input, second language learners will also gain speaking proficiency by listening to both authentic and connected speech in English and by doing oral work( as cited in Warsi, 2004).

L1 interference has important implications in the learning of written expression. L1 learning is different from L2 learning, as the person already knows about meaning and use of one language. First language helps learners when it has elements in common with L2, but hinders the learning process when both language systems differ (Cook, 2001). A person who speaks two languages has gone through the acquisition process twice, but second language learning takes many forms and occurs in many situations other than natural circumstances which cause problems (Cook, 1993). As discussed by Jansson (2005) it is impossible to avoid making errors when acquiring a second language. Students make different types of errors and they can be identified as lexical errors, grammatical errors and discourse errors. Lexical errors are mistakes learners make when they choose the wrong word for what they want to express: my brother was stopping in the door instead of standing. Grammatical errors concern mistakes in the form of words e.g. "we speaked'. Discourse errors relate to how sentences are made and put together in order to make whole texts. Most of the time the errors overlap in more than one of the categories listed above, which means that the type of error is not always as clear as in these examples (Thornbury,1999).

English is taught as a second language in Pakistan. It seems relevant to understand the concept of second language acquisition as viewed and understood by Pakistani students and teachers. Ellis (1997) and Gas and Selinker (2008) define the 'Second Language Acquisition' as the way in which the people learn a language other than their mother tongue, inside or outside the classroom. It refers to the learning of a non-native language after the learning of a native language. It means the acquisition of a second language in classroom situation as well as in more 'natural' exposure situations. Unfortunately, in Pakistan, teaching of English is confined to classroom teaching only. Little attempt is made to develop a language learning environment at school or institution level. It has been observed 
that students and even teachers speak in their mother tongue while teaching and learning English. Hence the students are not exposed to a learning culture which is peculiar to learning and practicing all the target languages (Asif, 2013).

According to Warsi (2004) most English language programs in Pakistani rural areas neglect oral work and engage students in translating text from Urdu into English and vice versa. The translation method impedes the acquisition of syntactic structures in that it relies heavily on isolated chunks of grammar, ignoring the context in which the sentences are uttered by native English speakers.

In Pakistan, it is important to get equipped with grammar knowledge as it is a part of English which is a compulsory subject in the curriculum. Previous studies have proposed that in written form especially, English as a Second Language (ESL) learners committed common grammatical errors that showed their incompetency in some grammar aspects (Zulaikha, 2013). Students face difficulties in the use of correct sentence structure and paragraph development, and in creating a coherent form. Grammar skills include run-on sentences, fragments and verbiage, inclusion of necessary information, use of different type of sentences, subject-verb agreement, and placement of modifiers, tense agreement and parallel construction (Leisak, 1989).

At one point or other, every teacher has probably thought about why students do not embrace what they are taught, but instead tend to make the same grammatical errors over and over again. Moreover, students think about why they, after many years of studying English, still struggle with the same errors. In order to improve our language skills we need to develop an understanding of the errors we make. Learners should take responsibility for their own learning process along with guidance from the teacher. Process-writing, problem-solving, task-based and structure-based activities all seem to have an impact on learners' language awareness (Köhlmyr, 2001).

Hendrickson (1980) observed that it is virtually impossible to avoid errors when learning any new skills, particularly when leaning a foreign language. It means errors are natural for learners and it is important for second language learners as Cadling (2001) claims that learners' errors are potentially important for understanding of how the second language is acquired. Olasehide (2002) also maintains that learners' errors are unavoidable and necessary for learning. So errors are not bad but it is a proof that learning is taking place as Broughton (1994) argued that "the errors he makes are to be seen as a sign that learning is taking place"( as cited in Ahmad, 2011). 


\section{Research Methodology}

The current study is based at COMSATS Institute of Information Technology Lahore. COMSATS Institute of Information Technology is one of the largest and fastest growing research- focused higher education institutions of Pakistan. The university is offering many programs in the field of Computer Sciences, Engineering, Management Sciences, Social Sciences, Physics, Statistics, Architecture, and Mathematics. The sample population is selected from different programs offered here which are BS Economics, BCS, BS Physics, BS Chemical, and BS Psychology. The undergraduates are studying here in their first semester and they are learning grammar and essay writing in the course of English Comprehension and Composition by the researcher and other English language teachers there.

\section{Sample Size}

The target population is two hundred undergraduate students of COMSATS Lahore, who are learning English in ESL classrooms and English Language teachers. The participants are both male and female from urban and rural back grounds. Participants are between 18 to 20 years old. They are registered in the English Comprehension and Composition course which is the First semester course of their degree program. The current study employs a mixed method design which includes both quantitative and qualitative research methods.

\section{Data Analysis}

\section{Students' Questionnaire Analysis}

\section{Student Perception of Essay Writing}

The first item of the research instrument focused on their attitudes towards essay writing. Participants provided responses whether they enjoy essay writing or not.

Table 1

Essay Writing is Enjoyable.

\begin{tabular}{|c|c|c|c|c|c|c|}
\hline & & $\begin{array}{lr}\text { Fre } \\
\text { quency }\end{array}$ & ercent & Percent & Valid & $\begin{array}{l}\text { Cumul } \\
\text { ative Percent }\end{array}$ \\
\hline \multirow[t]{3}{*}{ Valid } & Disagree & 8 & .0 & & 4.0 & 4.0 \\
\hline & Disagree & 13 & .5 & & 6.5 & 10.6 \\
\hline & Neutral & 52 & 6.0 & & 26.1 & 36.7 \\
\hline
\end{tabular}




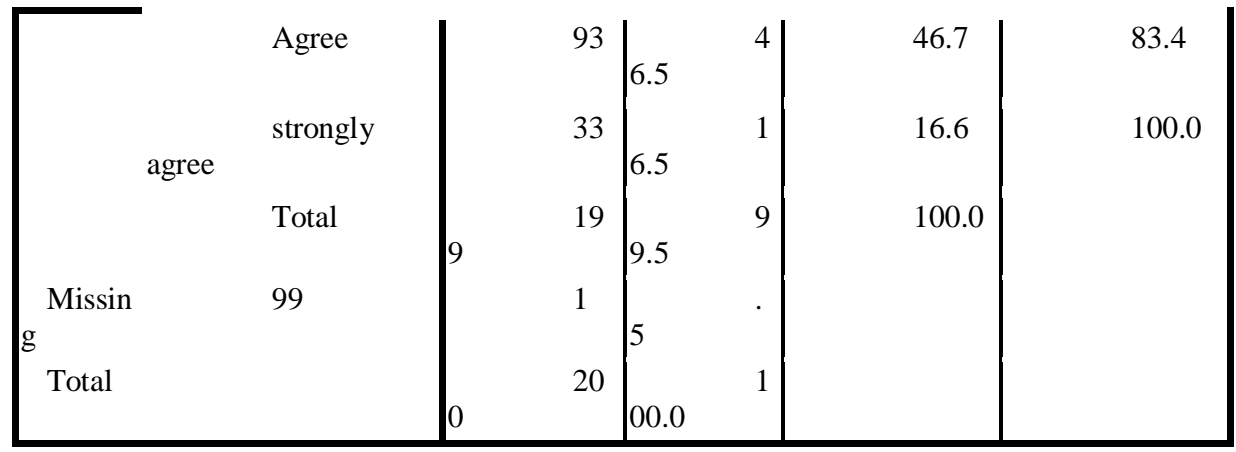

Table 1 above shows how they rated the statement. 63\% participants rated it as enjoyable. While $26 \%$ of them could not agree or disagree with the statement. $10.5 \%$ of the participants clearly do not enjoy essay writing.

Table 2

Rote learning is a good learning strategy to write in English

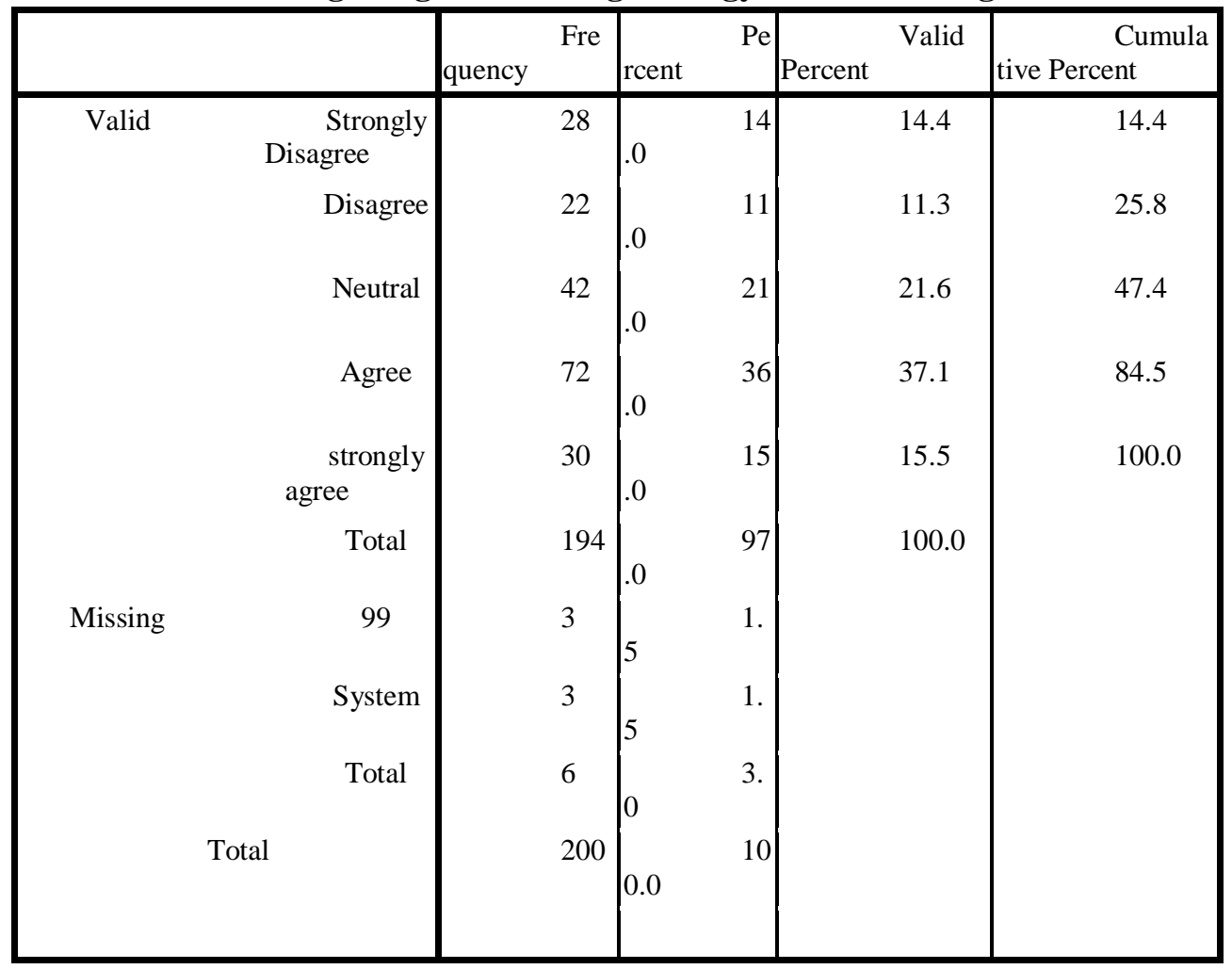

Participants were asked to give their opinion on using rote learning strategy to write in their L2. 51\% agreed that rote-learning is a good strategy to 
write in English whereas $25 \%$ disagreed. $21 \%$ did not mention whether they agree or disagree.

Table 3

You think that reading habit can improve your essay writing skills.

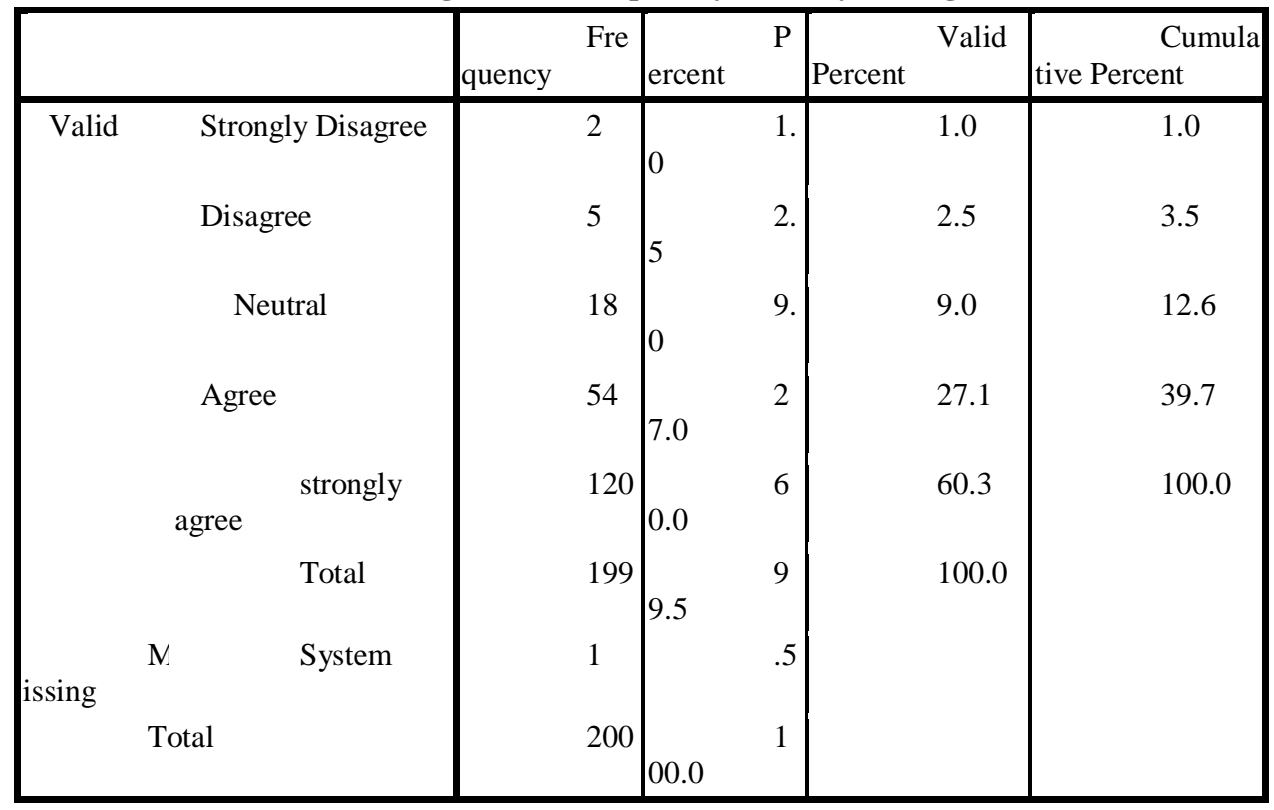

When participants were asked about their perception regarding reading habit $87 \%$ agreed with the statement. Only 3.5\% disagreed and $9 \%$ did not show their response clearly.

Table 4

Most of your sentences are grammatically correct.

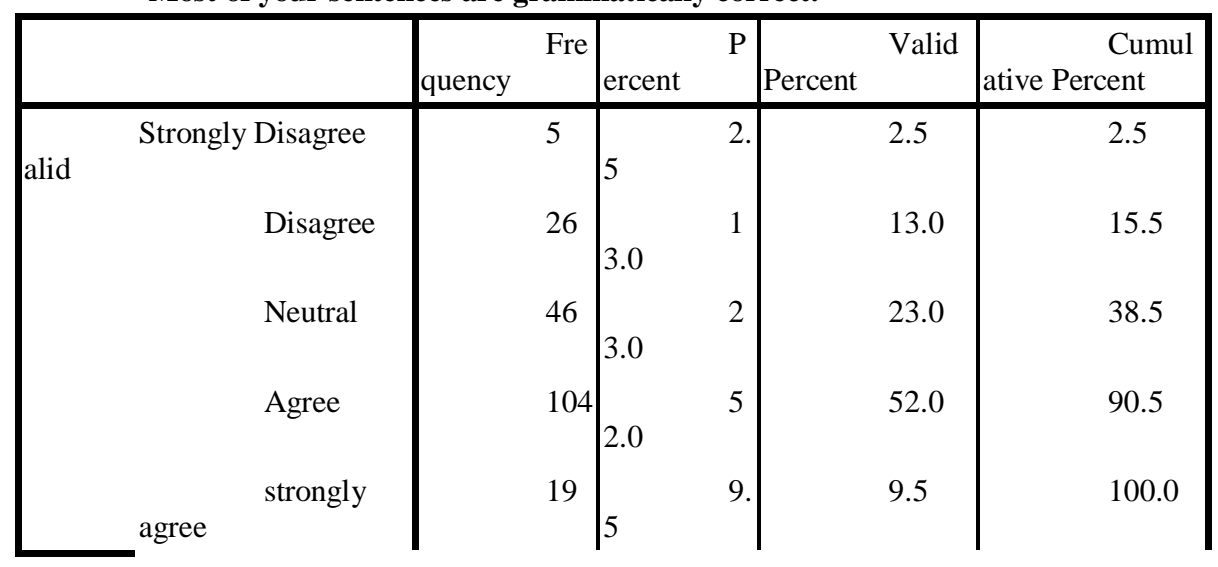


Most of your sentences are grammatically correct.

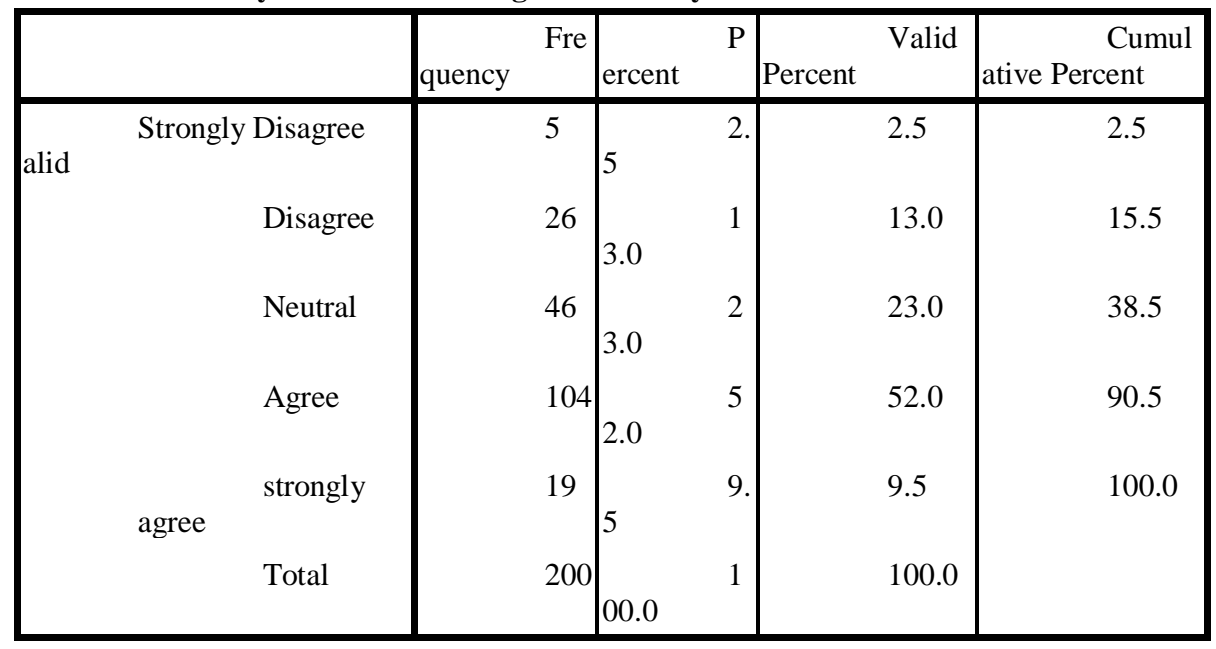

Participants were asked to give their perception of grammar application in their sentences.61.5\% think that their sentences are grammatically correct. $15.5 \%$ accepted that their sentences are grammatically incorrect whereas $23 \%$ had no clear idea that whether they are correct or not.

Table 5

You mostly have prior knowledge about the given topic.

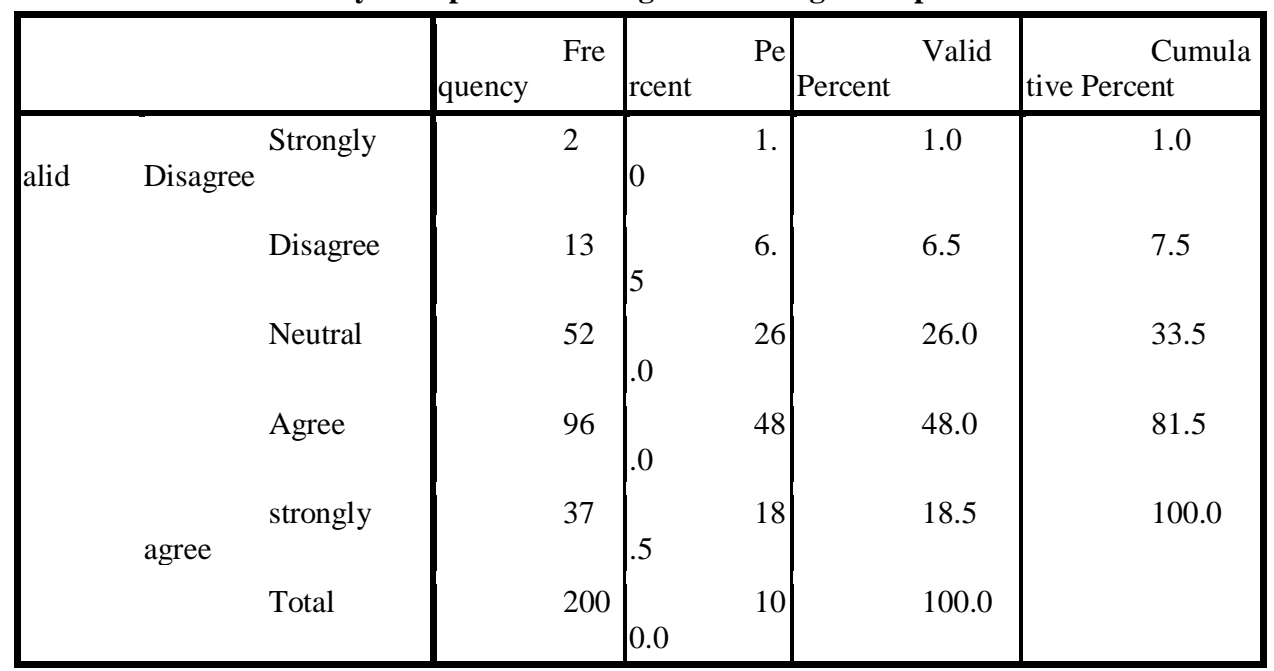

On asking about their prior knowledge about the topics in exams $66 \%$ said that they do have prior knowledge about the topics in exams.7.5\% disagreed and $26 \%$ were confused in their response and showed it neutral. Table 5 below tells the analysis. 
Table 6

You understand how to write sentences using the correct tenses.

\begin{tabular}{|c|c|c|c|c|c|}
\hline & & $\begin{array}{ll}\text { Fre } \\
\text { quency }\end{array}$ & rcent $\quad \mathrm{Pe}$ & $\begin{array}{ll}\text { Percent } & \text { Valid } \\
\text { Per }\end{array}$ & \begin{tabular}{|l|} 
Cumula \\
tive Percent
\end{tabular} \\
\hline Valid & Strongly Disagree & 6 & 0 & 3.0 & 3.0 \\
\hline & Disagree & 18 & 0 & 9.0 & 12.1 \\
\hline & Neutral & 34 & .0 & 17.1 & 29.1 \\
\hline & Agree & 88 & .0 & & 73.4 \\
\hline & strongly agree & 53 & 26 & 26.6 & 100.0 \\
\hline & Total & 199 & $.5 \quad 99$ & 100.0 & \\
\hline Missing & System & 1 & .5 & & \\
\hline Total & & 200 & $0.0 \quad 10$ & & \\
\hline
\end{tabular}

Participants were asked to tell their understanding of tenses while writing. The data analysis shows that $70.5 \%$ were confident about their understanding of correct tenses while $17 \%$ were not sure and $12 \%$ disagreed that they know how to write sentences using the correct tenses..

Table 7

You think of a sentence in Urdu first and then translate it into English.

\begin{tabular}{|c|c|c|c|c|c|}
\hline & & $\begin{array}{ll} & \text { Fre } \\
\text { quency } & \end{array}$ & 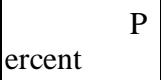 & $\begin{array}{ll} & \text { Valid } \\
\text { Percent }\end{array}$ & \begin{tabular}{|l} 
Cumula \\
tive Percent
\end{tabular} \\
\hline \multirow[t]{5}{*}{ Valid } & Disagree ${ }^{\text {Strongly }}$ & 21 & 1 & 10.6 & 10.6 \\
\hline & Disagree & 27 & 3.5 & 13.6 & 24.1 \\
\hline & Neutral & 49 & 4.5 & 24.6 & 48.7 \\
\hline & Agree & 58 & 9.0 & 29.1 & 77.9 \\
\hline & strongly agree & 44 & 2.0 & 22.1 & 100.0 \\
\hline
\end{tabular}




\begin{tabular}{|ll|l|l|l|l|l|}
\hline & Total & 199 & & 9 & 100.0 & \\
Missing & System & 1 & & .5 & & \\
Total & & 200 & 1 & & & \\
\hline
\end{tabular}

Table 7 shows that $51 \%$ participants think of a sentence in Urdu and then translate it into English.24\% did not clearly disclose whether they think in Urdu first or not and $24 \%$ disagreed with the statement. For them there is no difficulty to directly write their ideas in English

Table 8 essays in Urdu?

You think that writing essays in English are difficult as compare to writing

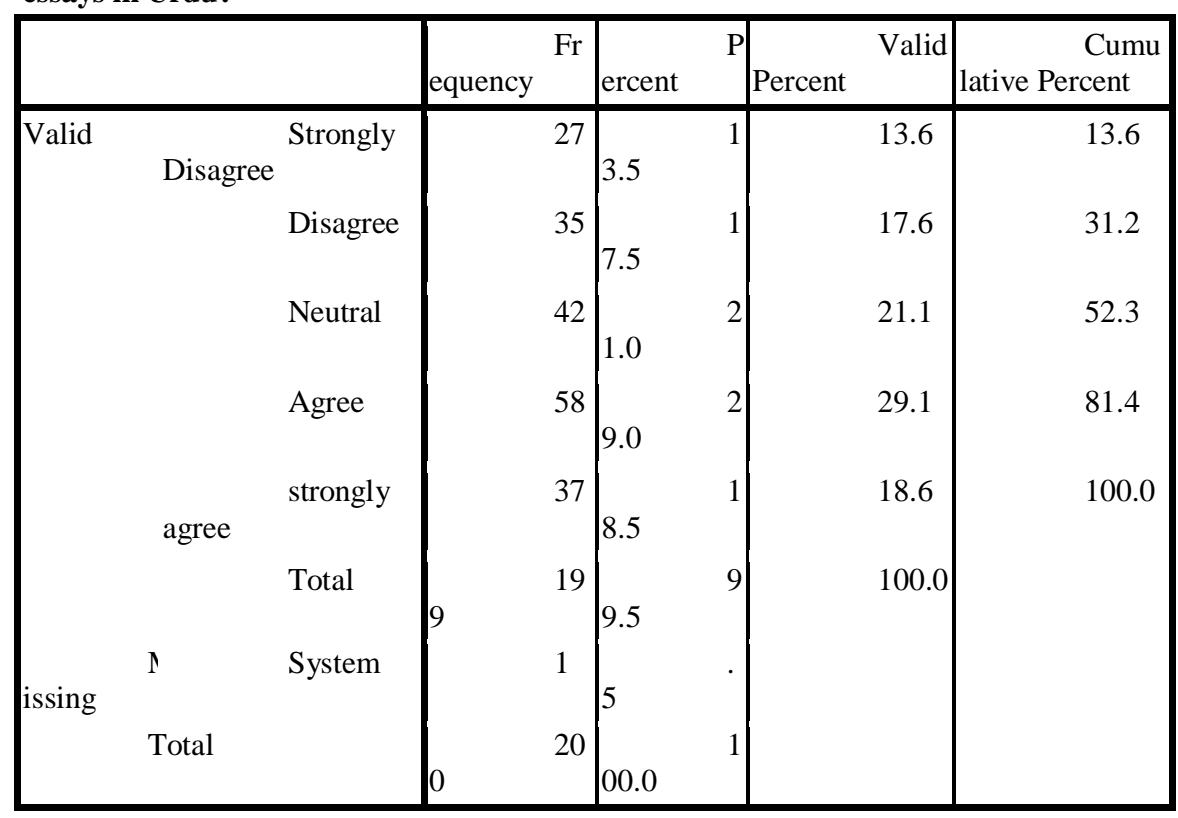

Responses at statement on difficulty of English essay writing as compare to Urdu essay writing showed that $47 \%$ agreed that it is difficult to write essays in English, $21 \%$ were unsure and $30 \%$ disagreed. 
Table 9

Using articles appropriately is one of the challenges for you while writing essays.

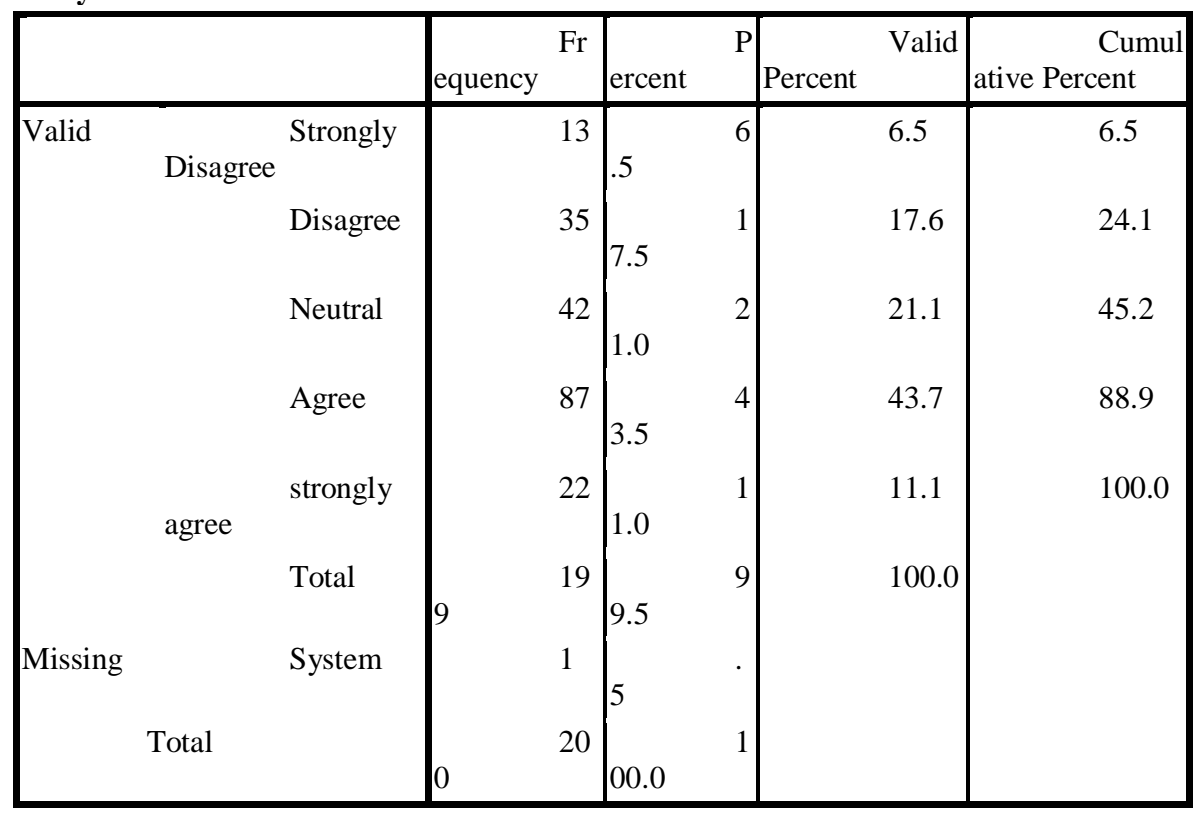

On using appropriate articles $54.5 \%$ agreed that article are one of the challenges they face while writing essays. $21 \%$ did not clearly mention and $24 \%$ disagreed.

\section{Student Perception of Major Challenges}

Respondents were requested to tell the major challenge that they face while writing essays.43\% face difficulty in using correct tenses and $49 \%$ said that subject-verb agreement is their major issue. $40.5 \%$ think that articles are their major issue. Subject-verb agreement was rated the major issue for them.

Table 10, 11,12, 13 below show the data in detail and frequency rate 
Table 10

Major problem correct use of tenses.

\begin{tabular}{|c|c|c|c|c|c|c|c|}
\hline & & & \begin{tabular}{ll|} 
& Fre \\
quency &
\end{tabular} & ercent & $\mathrm{P}$ & Percent & $\begin{array}{l}\text { Cumula } \\
\text { tive Percent }\end{array}$ \\
\hline Valid & Disagree & Strongly & 21 & 0.5 & 1 & 10.6 & 10.6 \\
\hline & & Disagree & 49 & 4.5 & 2 & 24.6 & 35.2 \\
\hline & & Neutral & 43 & & 2 & 21.6 & 56.8 \\
\hline & & Agree & 55 & & 2 & 27.6 & 84.4 \\
\hline & agree & strongly & 31 & & 1 & 15.6 & 100.0 \\
\hline & & Total & 199 & & 9 & 100.0 & \\
\hline Missing & & System & 1 & & .5 & & \\
\hline
\end{tabular}

Major problem correct use of tenses.

\begin{tabular}{|c|c|c|c|c|c|c|c|c|c|}
\hline & & & quency & Fre & ercent & $\mathrm{P}$ & Percent & Valid & \begin{tabular}{|l|} 
Cumula \\
tive Percent
\end{tabular} \\
\hline \multirow[t]{6}{*}{ Valid } & Disagree & Strongly & & 21 & 0.5 & 1 & & 10.6 & 10.6 \\
\hline & & Disagree & & 49 & 4.5 & 2 & & 24.6 & 35.2 \\
\hline & & Neutral & & 43 & & 2 & & 21.6 & 56.8 \\
\hline & & Agree & & 55 & & 2 & & 27.6 & 84.4 \\
\hline & agree & strongly & & 31 & & 1 & & 15.6 & 100.0 \\
\hline & & Total & & 199 & & 9 & & 100.0 & \\
\hline Missing & Total & System & & $\begin{array}{l}1 \\
200\end{array}$ & 00.0 & $\begin{array}{l}.5 \\
1\end{array}$ & & & \\
\hline
\end{tabular}

Major problem correct use of subject-verb agreement.

Int.J. Hum. Soc. Dev. Res.

Volume 1, № 1, 2017.19-41 


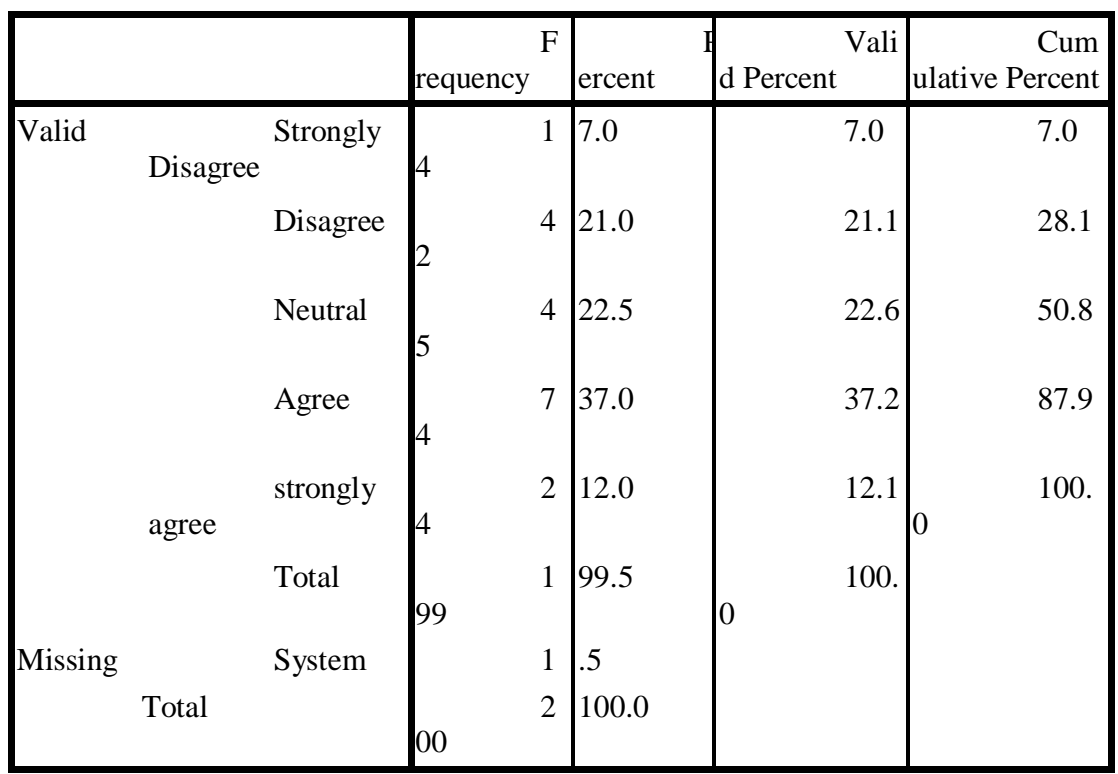

Major problem correct use of articles.

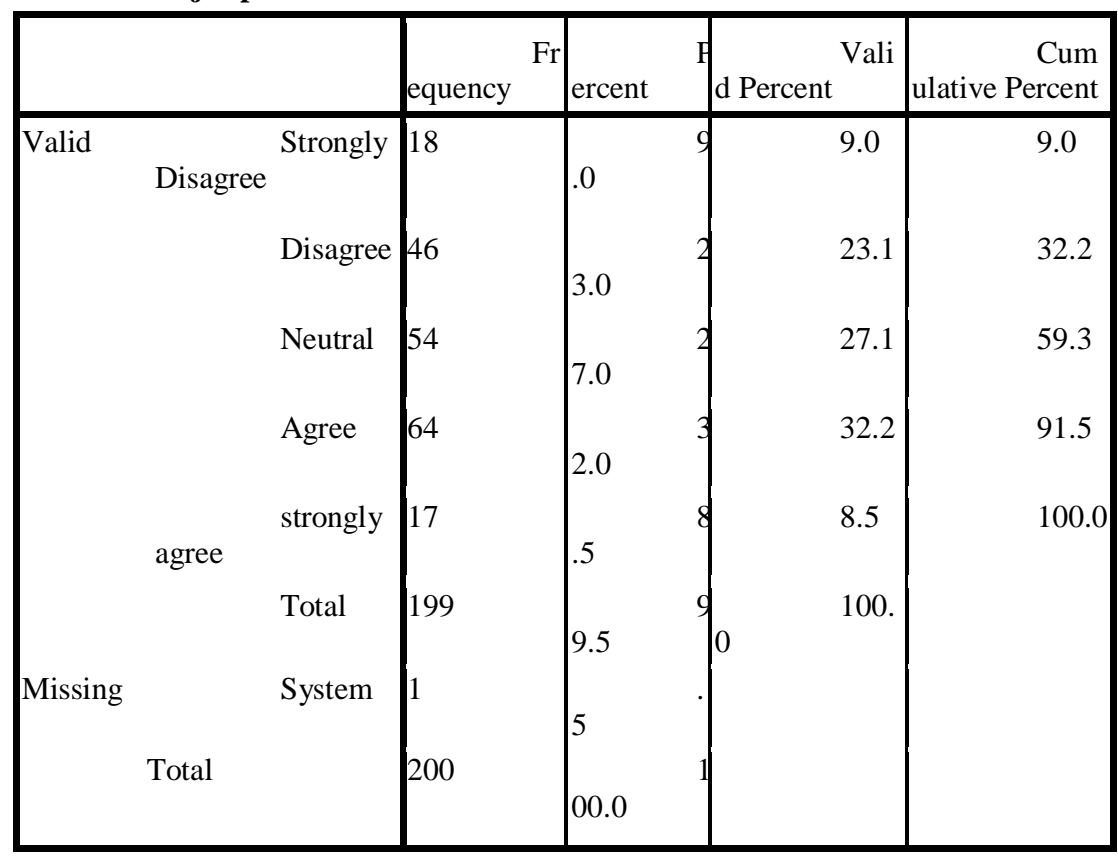


Table 14

Grammatical mistakes negatively affect your essay writing.

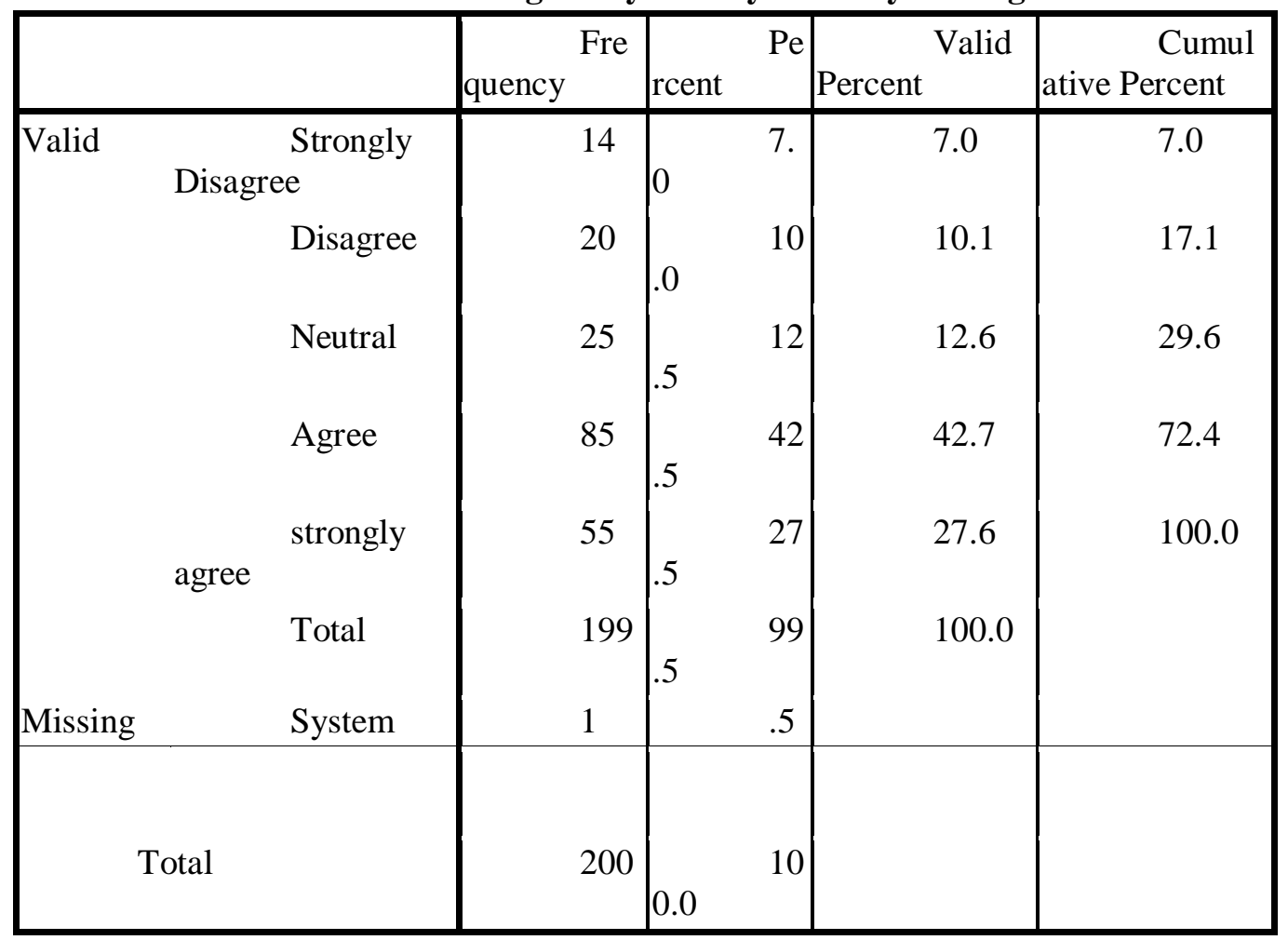

Students were asked to reflect upon the relationship between grammar mistakes and essay writing and they were requested to give feedback. $70 \%$ of the participants agreed that grammatical mistakes negatively affect their essay writing. $17 \%$ disagreed while $12.5 \%$ were unaware whether these mistakes affect or not.

Table 15

You feel difficulty in learning the rules of grammar.

\begin{tabular}{|c|c|c|c|c|c|}
\hline & & $\begin{array}{l}\text { Fre } \\
\text { quency }\end{array}$ & rcent $\quad \mathrm{Pe}$ & $\begin{array}{l}\text { Valid } \\
\text { Percent }\end{array}$ & $\begin{array}{l}\text { Cumul } \\
\text { ative Percent }\end{array}$ \\
\hline \multirow[t]{2}{*}{ Valid } & Disagree $^{\text {Strongly }}$ & 20 & 10 & 10.1 & 10.1 \\
\hline & Disagree & 53 & .5 & 26.8 & 36.9 \\
\hline
\end{tabular}




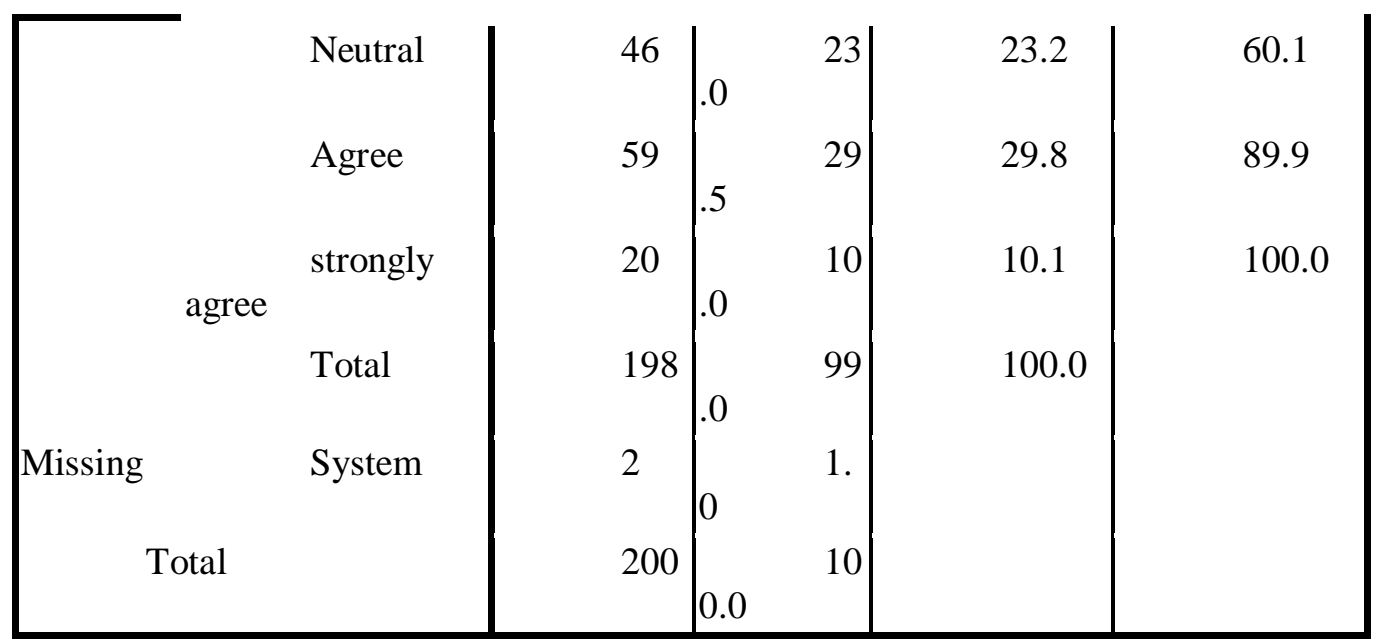

As showed in table 15, 39.5\% participants feel difficulty in learning the rules of grammar. $23 \%$ was unsure and $36.5 \%$ disagreed that they feel any difficulty in learning grammar rules.

Table 16

You do not get individual attention to understand grammar due to large class size

\begin{tabular}{|c|c|c|c|c|c|}
\hline & & $\begin{array}{r}\text { Fre } \\
\text { quency }\end{array}$ & rcent $\quad \mathrm{Pe}$ & Percent & $\begin{array}{l}\text { Cumul } \\
\text { ative Percent }\end{array}$ \\
\hline \multirow[t]{6}{*}{ Valid } & Disagree $^{\text {Strongly }}$ & 11 & 5. & 5.6 & 5.6 \\
\hline & Disagree & 53 & 26 & 26.8 & 32.3 \\
\hline & Neutral & 47 & 23 & 23.7 & 56.1 \\
\hline & Agree & 55 & 27 & 27.8 & 83.8 \\
\hline & $\begin{array}{ll} & \text { strongly } \\
\text { agree } & \end{array}$ & 32 & 16 & 16.2 & 100.0 \\
\hline & Total & 198 & .0 & 100.0 & \\
\hline Missing & System & 2 & 0 & & \\
\hline
\end{tabular}


You do not get individual attention to understand grammar due to large class size

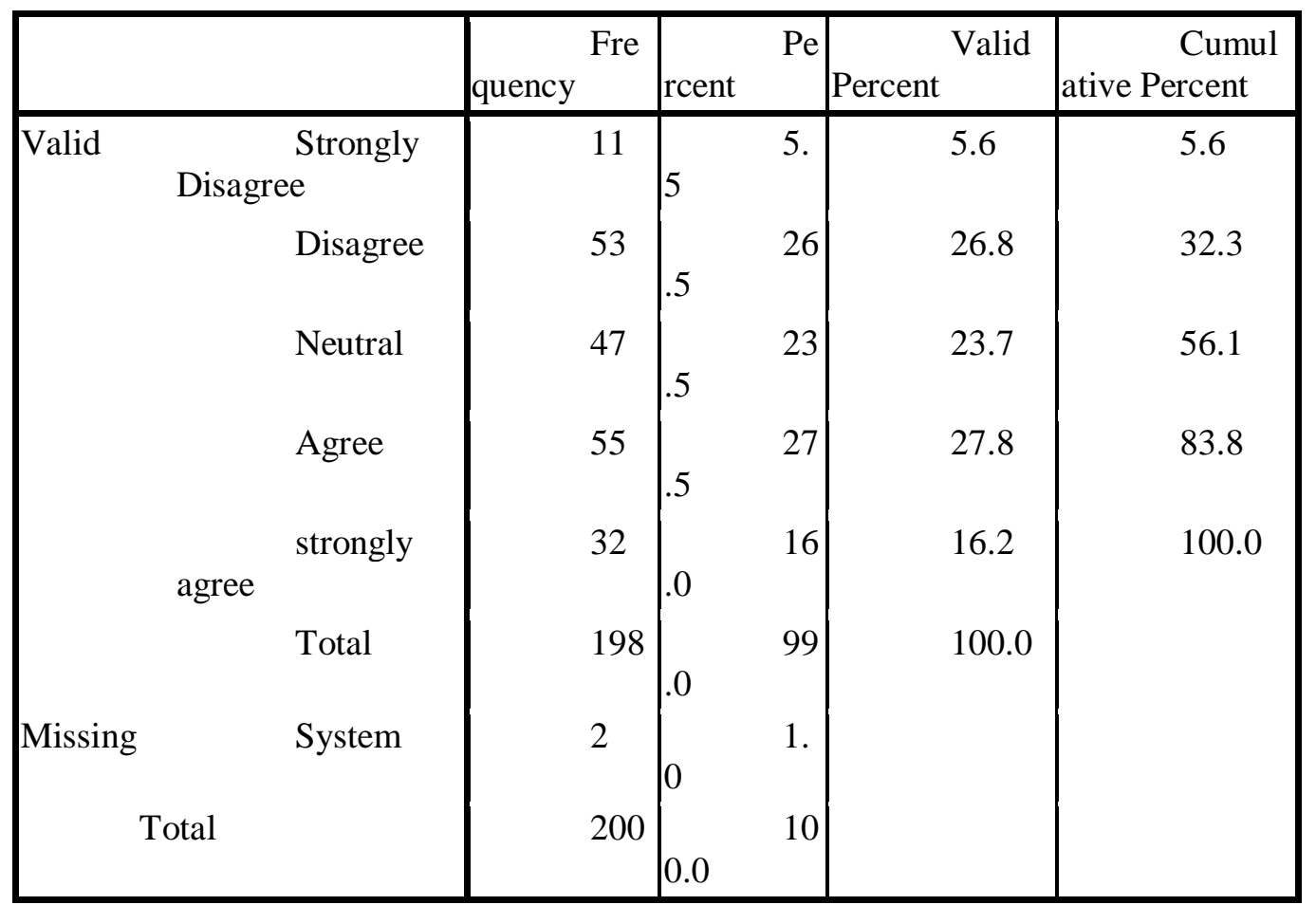

For collecting their feedback on the large class size they were asked to give response about it. The data shows that $43 \%$ agree that large class size is a hindrance in getting individual attention for learning grammar. $32 \%$ disagreed and $23.5 \%$ did not show clear response.

Table 17

SMS language has negatively affected your spellings and grammar.

\begin{tabular}{|c|c|c|c|c|c|c|}
\hline & & quency & rcent & $\mathrm{Pe}$ & Percent & \begin{tabular}{|r} 
Cumul \\
ative Percent
\end{tabular} \\
\hline \multirow[t]{3}{*}{ Valid } & Disagree $^{\text {Strongly }}$ & 20 & .0 & 10 & 10.2 & 10.2 \\
\hline & Disagree & 24 & & 12 & 12.2 & 22.3 \\
\hline & Neutral & 25 & & 12 & 12.7 & 35.0 \\
\hline
\end{tabular}

Int.J. Hum. Soc. Dev. Res.

Volume 1, № 1, 2017.19-41 


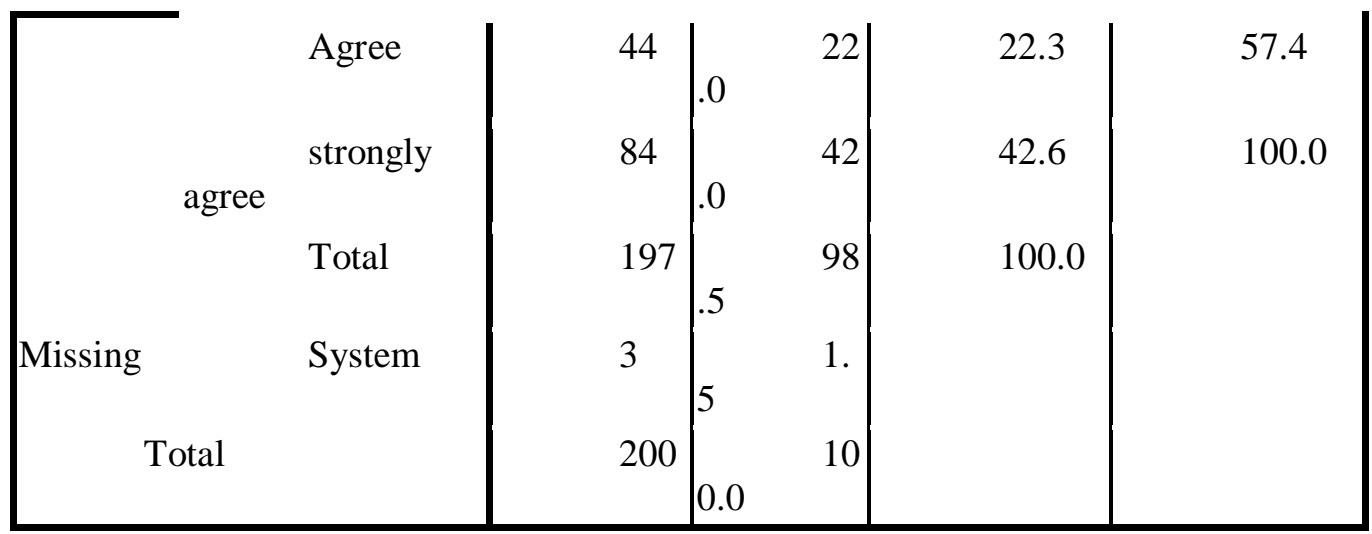

To check the influence of SMS language participants were requested to give their opinion. 64\% accepted that SMS language has negatively affected their spellings and grammar. $12.5 \%$ were unsure and only $22 \%$ disagreed with the statement.

Table 18

English grammar is difficult because it is so different from the grammar of your first language

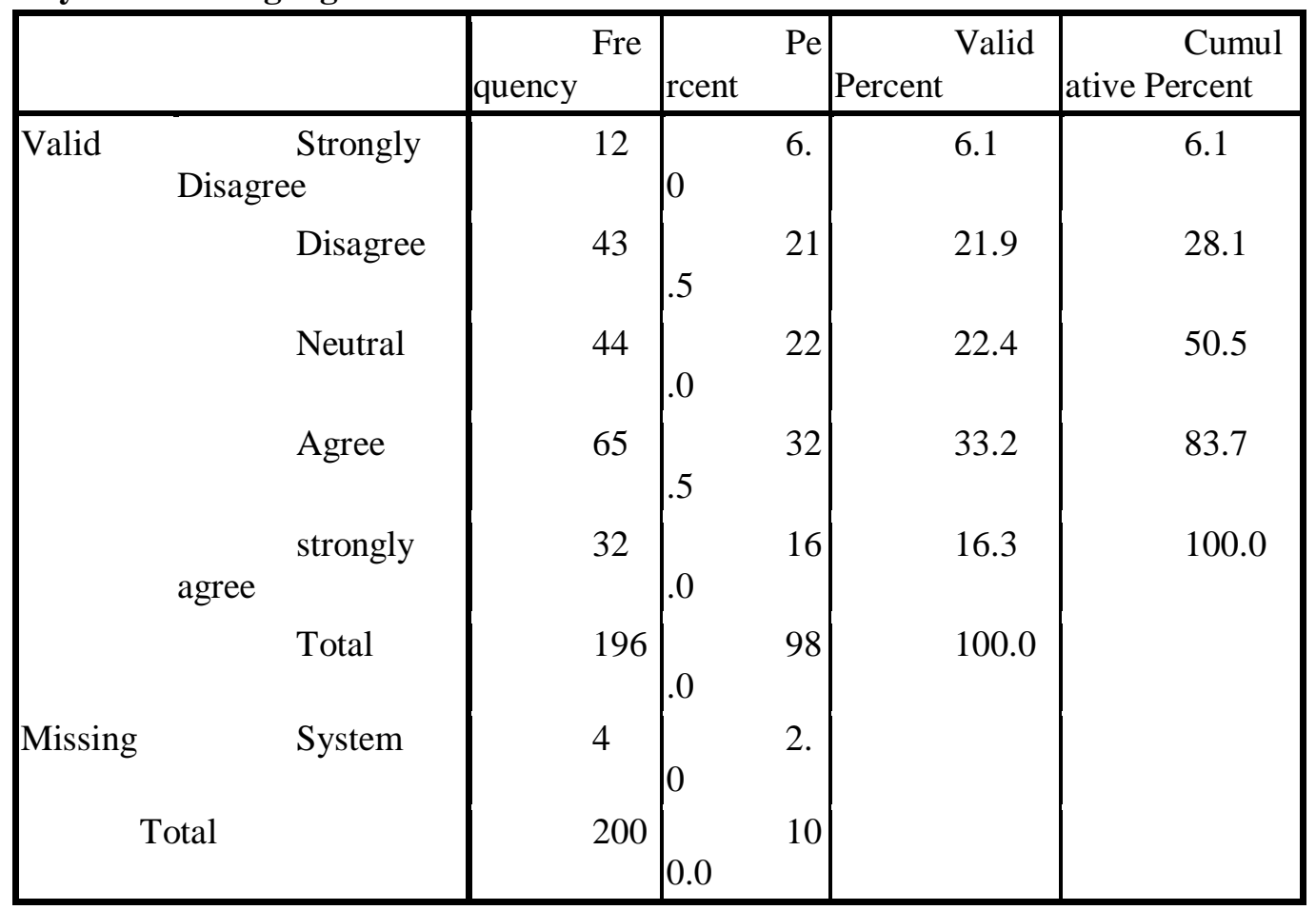


48.5\% respondents agree that English grammar is difficult because it is so different from their first language's grammar.22\% were unaware and 27.5\% disagreed the statement.

\section{Discussion}

Essay Writing is a tough process and a successful essay is drafted by the virtue of correct implementation of grammatical rules. The findings of this research show that the most common errors which students make are related to subject-verb agreement, tenses and articles. Many students take subject-verb agreement as a major challenge in their essay writing. Previous studies have proposed that in written form especially, English as a Second Language (ESL) learners committed common grammatical errors that showed their incompetency in some grammar aspects (Zulaikha, 2013). Students face difficulties in the use of correct sentence structure and paragraph development, and in creating a coherent form. Grammar skills include run-on sentences, fragments and verbiage, inclusion of necessary information, use of different type of sentences, subject-verb agreement, and placement of modifiers, tense agreement and parallel construction (Leisak, 1989).Expected from the previous studies the major problems students face are subject-verb agreement followed by tenses and articles. It is discovered that for $49 \%$ students subject-agreement is the biggest challenge while writing essays in English. In another response $54.5 \%$ said that the use of appropriate articles in also one of the challenges in English essay writing and this response relates to another finding that $48.5 \%$ participant believes that English grammar is different from their first language Urdu.

Urdu language does not have articles thereby it creates confusion and difficulty for ESL learners to learn the appropriate use of articles. As presented in the statistics, it is discovered that the common errors and problems are subjectverb, and tenses followed by articles.

It is clear that the major reasons of grammar errors are rote -learning, L1 interference, use of SMS language, and difference between Urdu and English grammars. Texting and using SMS language has highly contributed in grammar errors and ineffective essay writing. Data shows that $64 \%$ participants agreed that SMS language has negatively affected their spellings and grammar learning. $43 \%$ students said that improvement and understanding is not possible in large classroom size .They do not get individual attention to learn grammar due to large class size. Data shows that rote-learning is another major reason of ineffective essays. Rote- learning and memorizing destroy the writing skills of students. Students memorize to avoid the cognitive process of creative writing. 


\section{Conclusion}

There are several recommendations proposed based on literature, findings of the study and for implication for future studies. The recommendations are proposed to those related in the educational field, those involved in the process of language learning and teaching as well as researchers. Based on this study, it is required to give emphasis on subject-verb agreement and tenses in grammar learning. Therefore, the syllabus and curriculum designers for English might be able to consider focusing more on that part of grammar item to be implemented in English classrooms. Teachers should motivate students to develop reading habit as a part of their life. Reading improves speaking skills along with written expression. Students should be encouraged to read more in order to familiarize themselves with the correct usage of Standard English. For its real implementation and for students' involvement, book reviews can be given as assignments or presentations so that they can read at least one book thoroughly.

Learners should be encouraged to think in the target language rather than in their native language when writing. Students should be taught to handle the first language interferences especially how to avoid the mistakes created due to L1 syntax. Application of grammar rules should be focused. The overt influences of Urdu language on students' writing of English essays indicate that language teachers need to take care of the transfer and interference of the students' mother tongue in their spoken or written production. It can be informative and necessary to tell the differences between the native tongue and the second language in formal lessons

It is true that it is difficult to teach students useful grammar only through explicit teaching. Grammar books may help students succeed in examinations, but they alone are not sufficient to give them communicative competence. To achieve this objective, grammar teaching should be improved by showing grammar rules in real-life, in authentic situations and also by giving students opportunities to use the forms in real contexts. Grammar contributes to meaning and should be taught in meaningful contexts.

Teachers can draw their students' attention to the differences between the native and foreign languages. In this case, second or foreign language learners' sensitivity and awareness of these differences will be raised, and that might help students reduce their interference errors. There is no doubt that the native language plays an important role in learning and using another language, especially in foreign-language learning situations where the learners' exposure to the target language is confined to a few hours per week of classroom instruction.( Hourani, 2008). A better understanding of the L1 influence in the process of EFL writing will help teachers know students' difficulties in learning English. It will also aid in the adoption of appropriate teaching strategies to help beginning EFL students 
learn English writing skills better. As Richards \& Renandya (2002, p. 303) claim; "there is no doubt that writing is the most difficult skill for L2 learners to master. The difficulty lies not only in generating and organizing ideas, but also in translating these notions into legible text".

The study leads to the need of an extended study. There are many considerations in terms of scale, methodology, sample size, data analysis strategy and factors causing difficulties in essay writing and application of English grammar. To have a larger scale of sample would increase the reliability of the findings. It is recommended that further research should be undertaken to investigate the errors made by undergraduate students majoring in English. It would be interesting to compare experiences of students' writing L2 from high school and university for the purpose of examining the common errors produced by them.

\section{Disclosure statement}

No potential conflict of interest was reported by the author. 


\section{References and notes:}

Ahmad, N. (2010). Error analysis: Learning articles and prepositions among secondary school students in Pakistan. Institute of Interdisciplinary Business Research,2.

Aronoff, M., \&, Rees-Miller, J. (2007). The handbook of linguistics. Oxford: Blackwell. Asif, M. (2013). Using the literature to address a problem/issue in writing. International Journal of Academic Research and Reflection, 1,1-7.

Cai, G. (2004). Beyond bad writing: Teaching English composition to Chinese ESL students. (ERIC Document Reproduction Service No. ED 364104).

Hughes, R. (1996). English in speech and writing. New York: Routledge.

Jansoon, P. ( 2005). Learning by doing can students become more proficient in grammar Through feedback by underlining? Institutionen för kultur och kommunikation. Retrieved from http://www.kau.se.

Leisak, J. (1989). Problems in written expression: Assessment and remediation. New York: Guilford Press.

Murrow, P. (2005). Analysis of grammatical errors in students' writing-indicators for curricula enhancement. 松江工業高等専門学校研究紀要, 40, pp. 19-26.

Teorey, M. (2003). Using Freshman Composition to Analyze What Students Really know About Grammar. The Quarterly, pp. 25, 4.

Warsi, J. (2004). Conditions under which Enlish is taught in Pakistan: An applied linguistic perspective. Retrieved from http://www.sarid.net /sarid-journal/2004_Warsi.pdf.

Zulaikha, A. (2013). Grammatical errors committed by ESL upper secondary school learners in writing. Universiy of Pendidkan Sultan Idris

\section{Contact Information}

E-mail: maryamjahangir@ ciitlahore.edu.pk 